\title{
Coping in a harsh reality: The concept of the 'enemy' in the composition of Psalms 9 and 10
}

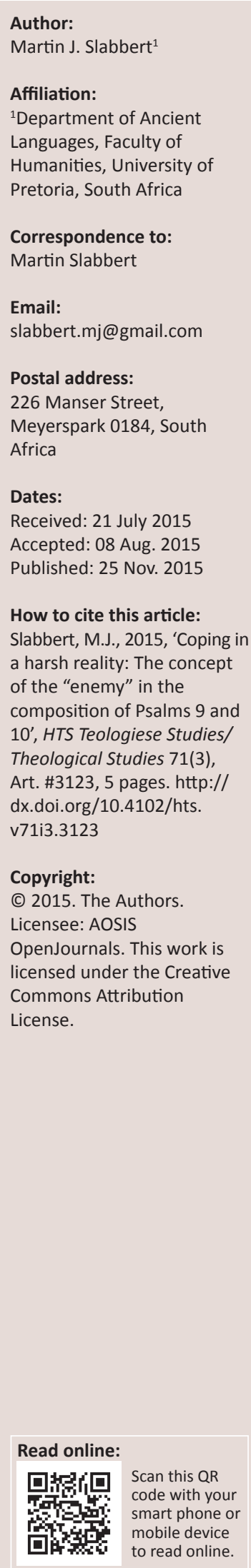

In this paper, Psalms 9 and 10 are read together from a literary, post-exilic perspective, arguing that the construct of the 'enemy' in this composition primarily serves to strengthen the position of the righteous. It seems that a variety of strategies are employed in this composition to establish dichotomic-ideological categories. This results in the formation of a polarity between YHWH and the enemy on the one hand and the righteous and the enemy on the other. This seems to have been a technique through which the author or authors of this composition sought to break free from their current social experience in order to create a new, just and fair reality for the righteous.

\section{Introduction}

Of the 150 Psalms in the Hebrew Bible there are more than 90 Psalms that refer to the pious or righteous and his struggle with the enemy, his counterparty. Any person who would like to come to a better understanding of the Psalms, needs to take the relationship between the pious and the enemy into account. It is generally accepted that David did not write all the Psalms, nor that all the Psalms precipitated in the same context. These insights have prompted researchers to seriously ask about the identity and circumstances of the pious poet and the enemy, who is the ' $\mathrm{I}$ ' and the 'enemy' in the Psalms (see e.g. Kittel 1922:82-83)? In the past, however, historical-critical research mainly focused on the identity and circumstances of the pious and the enemy, without actually asking about the functionality of the enemy. ${ }^{1}$

Gunkel and Begrich (1985:196-211, 226-227, 270) with their study of the cultic form and function of prayer and the psychological-aesthetic nature of prayer, brought a turning point to the view of enemies in the Psalms. In the uncertain stylistic and historical depictions of the enemy Gunkel and Begrich found a proof for their theory that the Psalms were written by different people in different circumstances and that they were repeatedly used. This approach has led them to make less of the external events in which the text was situated, and place more value on the psychological effects (den seelischen Eindrücken) of the text. Gunkel and Begrich (1985:200-206) have only gone so far as to identify three categories of the enemy in the Psalms, those related to: (1) sickness and accident, (2) hostile nations, especially in the time of the exile, and (3) antagonistic nations among whom the Jews have lived in the period after the exile.

The following nagging questions remain: Who is the enemy?, Is it necessary to define him?, Why does the enemy remain anonymous?, and What role does the enemy play in the Psalms?, or as Delekat (1967) puts it:

When the ones praying and their enemies ... are private persons, why do they turn to God for protection instead of the civil courts and how do they think of this protection? (p. 5)

I will apply these questions to Psalms 9 and 10. For the sake of this article Psalms 9 and 10 will be treated as closely related to each other.

\footnotetext{
1.There is no shortage of research that was done on Psalms 9 and 10 . The enemy has been interpreted in various ways in the Psalms Duhm (1922:15-23) and to some extent Kittel (1922:xxii-xxxii) regarded the enemy as political and religious opponents of the righteous in the Maccabean period. Puukko (1950:47-65) later elaborated on this. Balla $(1912: 16,19,125)$ argued from the premise that the ' $I$ ' in the Psalms is an individual, and therefore the enemy was considered a personal opponent of the faithful, presumably the unbeliever and therefore also enemy of God (see also Sanders 1976:101). Mowinckel ([1923] 1966:4, 81) reckoned that the enemies were mainly magicians who wanted to harass the believer and wanted to harm them through magic. With Gunkel and Begrich he argued that the enemy was usually seen as the one who caused personal illness. In contrast, Birkeland $(1955: 9-11,93-94)$ argued that the enemies were rather the enemies were rather external national enemies (also called Gentile evildoers) against whom Israel should wage war. Jenn (1976:119) also aligned himself to this argument when he stated: 'In den meisten Fallen sind politisch-militärische Feinde des Volkes Israel gemeint' (see esp. Christensen 1992:1037-1048 for a comprehensive discussion of the nations that threatened Israel). Widengren (1936:233) placed great emphasis on the influence of the Akkadian literature on the Old Testament texts. However, he held a more responsible position by highlighting the different contexts that determined the identity of the enemy. Each context, therefore, would determine whether the enemy is a personal or a universal enemy. The personal enemies he saw primarily as magicians who wanted to harm the righteous with magic. Following studies in semantic fields, particularly by Sawyer (1972), Rosenbaum (1974:54$55,77-78$ ) made a case that the terms 'enemy' and 'wicked' are not as synonymous as it was accepted in the past. Rosenbaum (1974)

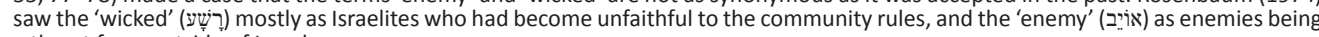
a threat from outside of Israel.
} 


\section{Semantic perspective}

Psalms 9 and 10 contain a large number of words in the word

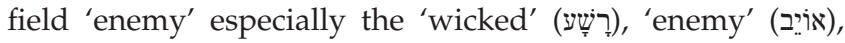

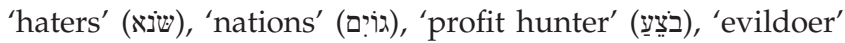
(ערָ) (עָריםם) and cities). De Saussure (1916) compared language to a chess game, consisting of certain elements and a set of rules for their combinatorial movement. Language is an inventory and a set of rules. A word being an element in language (like chess pieces) has a reciprocal relationship. A particular value is awarded to a bishop in accordance to its movement with respect to other pieces. The question of what value (meaning) words derive from their relationship with respect to other words in the lexicon is addressed by the study of word fields and semantic components.

One element of Semantics which may be helpful for this study is 'dichotomy'.

\section{Dichotomy}

Dichotomy is an important structuring principle in the lexicon whereby contradictions and counterparties are expressed. In a sense it could be considered as the opposite of synonymy. One aspect of dichotomy is complementarity.

\section{Complementarity}

Complementarity occurs when all the non-members of one class are members of another class, and vice versa. With regard to Psalms 9 and 10 this could be represented graphically in Figure 1.

There is no question of gradual differences. A person is righteous or not righteous.

The members of the complementary class always have within them an element of denial and are incompatible with the members of class $\mathrm{A}$. This feature aims to determine separateness of the primary class. An individual cannot be a member of the class as well as the complement of the class. If an individual's membership of such a class is confirmed, his membership of the complement of this class is simultaneously denied. To say that a party is just before God, implies to deny that this same party is not in the right relationship with God. The same principle applies to the enemy. Within this scheme the enemy would then fulfil the role to put the primary party (the righteous) in the right light. The characteristics of the righteous are positive whereas the characteristics of the enemy contrast with the righteous like the negative of an image. For this contrast to be presented in a strong way the righteous in Psalm 9 are associated with terms

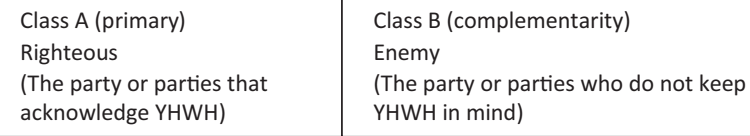

FIGURE 1: The enemy as member of the complementary class. such as oppressed (v. 10), they who know YHWH's name (v. 11), afflicted (vv. 13, 19) and the needy (v. 19). In Psalm 10 the righteous are grouped with the afflicted (vv. 2, 9 [2 times],12,17), the innocent (v. 8), the unfortunate (vv. 8, 10, 14), the fatherless (vv. 14, 18) and the oppressed (v. 18). All these terms are used in a positive light and evoke sympathy from the listener. The enemy is an essential villain to help create and reinforce this positive image of the righteous.

Although different names are used to portray the righteous and wicked respectively, all the members of each grouping show similar characteristics.

\section{Psalms 9 and 10 in a tri-angle}

Psalm 9 begins with praise due to YHWH's redemptive acts. On the basis of YHWH's redemptive acts in the past, the poet then appeals to $\mathrm{YHWH}$ to intervene in his new crisis. YHWH's intervention and judgment establishes the wicked's demise and does justice to the righteous. The song ends with the plea that YHWH cut the wicked back to size. Psalm 10 begins with the poet trapped in a crisis and there is no solution in sight. The wicked is doing well and the righteous not. Great emphasis is placed on the perception of the wicked that God is absent. This perception is in a certain sense also reflected in the feeling of the righteous that $\mathrm{YHWH}$ is not near. The righteous has further insight into the actions and thoughts of the wicked. On three occasions are words put in the enemy's mouth (see Coetzee 1997:2). All these words have a negative connotation and bear witness to the enemy's arrogance.

Although each of the Psalms is logically and stylistically put together and can be seen as separate Psalms, there is clearly a thematic agreement. YHWH is drawn into a crisis to help bring about a new perspective on the situation: $\mathrm{He}$ justifies the godly and turns the tables on the wicked. He is the only one who can change the position of both parties. There is a distinct triangular relationship between $\mathrm{YHWH}$, the righteous and the enemy that must be kept in balance for the sake of the righteous' meaningful functioning in his environment and society.

Already in 1964, Westermann (1964:269-295) pointed out the triangular relationship between $\mathrm{YHWH}$, the righteous and the enemy. By his appeal to YHWH the righteous seeks to confirm this triangle again and to stabilise his reality.

Bowen (1989) works with the theory that most relationships can be typified as triangular relationships. He puts it as follows:

The theory states that the triangle, a three-person emotional configuration, is the molecule or the basic building block of any emotional system, whether it is in the family or any other group. The triangle is the smallest stable relationship system. A two-person system may be stable as long as it is calm, but when anxiety increases, it immediately involves the most vulnerable person to become a triangle. When tension in the triangle is too great for the threesome, it involves others to become a series 
of interlocking triangles ... In periods of calm, the triangle is made up of a comfortable close twosome and a less comfortable outsider. (p. 373)

\section{Brueggemann (1991) rightly states:}

In this poem [Psalms $9 \& 10]$, the decisive party is Yahweh, who governs powerfully and equitably. Yahweh is the one who takes all the decisive actions. It is Yahweh, executor of judgement, whose actions determine the social position and possibility of the other two parties. (p. 4)

YHWH is the determining subject of these Psalms that work change and determine the respective positions. He has the final say. This aspect is supported by the high frequency of words in the legal domain (see for example the use of these

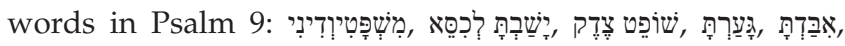

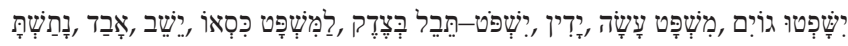

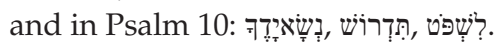

The righteous' adversary is always the enemy, nations, wicked, cities, haters, profit hunters and evildoers. These entities are in some instances used separately, in others together in synonyms and synthetic parallelisms, and in various other combinations (see for example Ps 9:6, 9, 18, 20 \& Ps 10:3). It rather looks as if the poet deliberately doesn't want to ascribe a stable and identifiable identity to the 'enemy', as may be the case in most of the other Psalms. Croft (1987:71) calls this phenomenon 'an empty metaphor'. There is no mention of a development of the term 'enemy' as Gattungskritik would like to have it. The difference lies rather on a stylistic level. In contrast to most studies on the identity of the enemy, this article comes to the conclusion that the functioning of the 'enemy' within the triangular relationship between $\mathrm{YHWH}$, the righteous and the enemy rather points to the identity and positioning of the faithful, instead of the 'enemy' himself. The faithful understands his relationship with YHWH in terms of the 'enemy's' relationship in respect of $\mathrm{YHWH}$ and $\mathrm{YHWH}^{\prime}$ 's negative relationship with the 'enemy'.

Schematically it can be portrayed in Figure 2.

This scheme would clearly indicate something of the spirituality of the righteous. ${ }^{2}$

\section{Claiming common ground}

Coetzee (1997) shows in his study of Psalms 9 and 10 that the poet successfully uses the rhetorical 'mechanism of claiming common ground' between the poet and YHWH as a strategy by which the poet tries to reposition himself. One way in which this 'common ground' can be achieved is through the strategy of exaggeration. The righteous will praise YHWH with all his heart, and proclaim all his wonders (9:1). The high frequency and emphasis on words in the praise-word field in 9:1-2 is striking. The further use of the praise verbs in the cohortative $(9: 1,14)$ is an indication of the poet's eagerness to identify 2.See in this regard also Botha (1986; 1992:252-263).

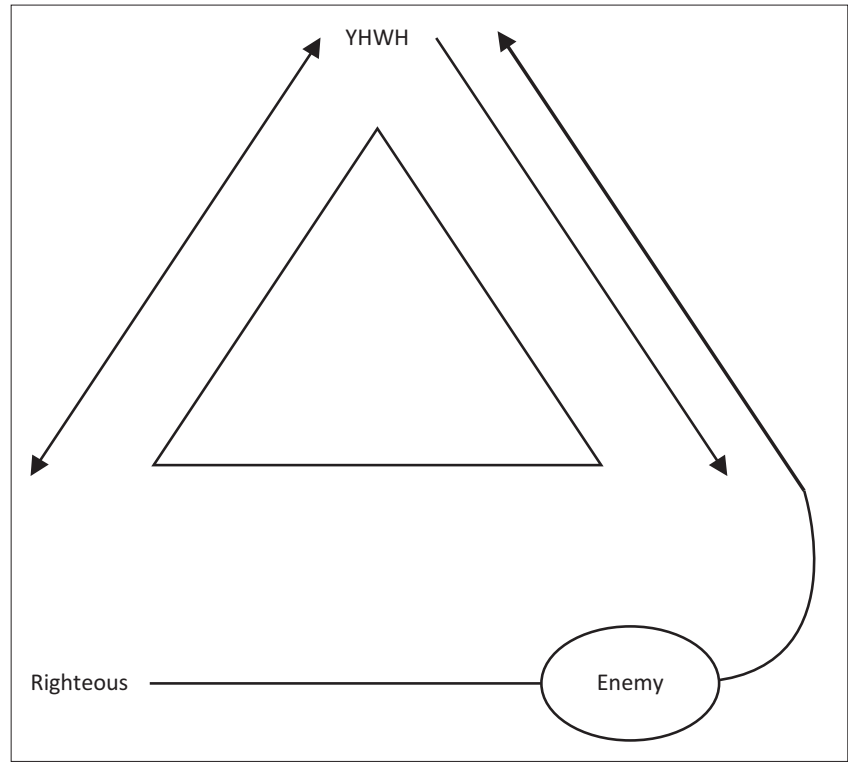

FIGURE 2: The functioning of the 'enemy' within the triangular relationship between $\mathrm{YHWH}$, the righteous and the enemy.

with YHWH. Words like 'come to an end - ruins forever' (9:6), 'will sit forever' (9:7), and references to the enemies and their fate $(9: 3,5-6,15-17,20)$, YHWH's judgment $(9: 4-5,8,16,19)$, and his throne $(9: 4,7,11)$ are all emphasising YHWH's positive action toward the righteous and his adverse action against the enemy. By referring to YHWH's punishment of the nations in the past (9:5), his eternal government (9:7, 18), the fact that he was a refuge for the oppressed (9:9), and that he does not forsake those who know his name and seek him (9:10), the righteous seeks legitimacy and consent with YHWH for whom he is, what he says and what he does.

Psalm 10 begins with the poet's technique of persuasion of putting words in the mouth of the enemy as a strategy to find 'common ground' with YHWH. The righteous poet in this hymn has first-hand insight into the thoughts, words and deeds of the enemy. The enemy is proud $(10: 2,4,5,13)$, boasts and ridicules $(10: 3,6,7,11)$, makes plans $(10: 2)$ and persecutes the righteous $(10: 2,8,9,10)$. Contrary to the righteous, the enemy does not want to seek YHWH. These negative qualities of the enemy are sketched in terms of his relationship with the righteous and also in respect of YHWH (in Psalm 9 the actions of the enemy was directed primarily at the righteous). This strategy aims to portray the enemy in a negative light in terms of his relationship with the righteous and $\mathrm{YHWH}$, which implies that the righteous actually enjoys the favour of YHWH and is associated with him. YHWH's reciprocal role is then to grant honour to the position and status of the righteous and to nullify the enemy (see e.g. Ps 9:20-21; 10:16-18).

In short: In both Psalms the righteous clearly comes off second best in his everyday life and that causes an unbalanced relationship with all parties in his life. In order to restore balance and maintain his status the righteous calls on 
a generally accepted authority outside of himself (YHWH), but also a party which no one in society can argue against.

Sheppard (1991) brings an additional perspective when he argues that:

$[T]$ hese prayers were traditionally spoken out loud and intended to be overheard by friends and enemies alike. ${ }^{3}$ In that case, they do not belong to the rhetorical resources characteristic of a private and individual catharsis, but express their complaints and desires publicly. (p. 64-65)

Through the public prayer the listening community is called to confirm the status and honour of the suffering righteous, and to shame the enemy. The prayer therefore aims to call $\mathrm{YHWH}$ as judge in public in order to establish social justice and to legitimise the status of the righteous - something that will have to be accepted by the society of the righteous.

It has been pointed out that the reality of the righteous is polemically constructed - a typical reality that features everywhere where social relationships of two parties exist. The problem in Psalms 9 and 10 is that this social relationship became distorted and unbalanced. Through his ideology the enemy attempted to negate God from everyday reality. The best examples are the words in the mouth of the enemy that appear in Psalm 10:

- 'There is no God' (v. 4).

- 'I will not be killed; from generation to generation [I] will be where there is no misfortune' (v. 6).

- 'God has forgotten, he hid his face, he will never see' (v.11).

- 'You will not seek?' (v.13).

All four statements are denials of God and speak of the complacency and autonomy of the enemy.

\section{Sitz im Leben}

In all probability the Psalms were complete approximately between $325 \mathrm{BC}$ and $250 \mathrm{BC}$ with a shift from a cultic use to a use for the purposes of personal life (cf. Gottwald 1985:525). Gottwald (1985) puts it as follows:

The move from a live cultic performance of psalms to their collection as literature was a major one, in which much of the actual cultic functioning of the psalms, both early and late, has been lost or obscured. It is evident that factors other than stated worship have had a part in the shaping of the Book of Psalms. In a measure, they reflect a tendency toward private 'devotional' use ... Nowadays it is judged that many of the psalms, while scarcely written by David, are pre-exilic, and that, among the many postexilic psalms, probably all of them were composed before Maccabean times. (pp. 525-526)

3.Sheppard (1991:78-82) in the footsteps of Gottwald has satisfactorily proposed that prayers in the Old Testament were mostly audible prayers, and had thus deliberately been made public. Through prayer there was an attempt to influence listeners, especially the enemy.

4.Sheppard (1991:69-82) illustrates his theory satisfactorily by means of practical examples of prayers in the Old Testament. See in this regard also Lewis (1976:140144).
In terms of a more personal Sitz im Leben I can surmise the following: The enemy is definitely stronger and has a greater power base than the poet. This power could only be obtained through greater economic means, and political or social abuse. This imbalance may cause a polemical construction and is maintained by the enemy's ideology - an ideology in which there is no room for God. Unchallenged power becomes the only legitimate power and it necessitates the poet to appeal to a higher power, namely YHWH. The poem, Psalms 9 and 10 as a whole, is an attempt by the righteous to bring YHWH into this reality and to restore the balance. Prayer is therefore in this sense a political act.

\section{Conclusion}

The presupposition by several commentators that the text comes into existence from the social reality is not entirely satisfactory. By implication the righteous would have accepted his fate and tried to live in his distorted reality with the least conflict. Clearly this is not the case in Psalms 9 and 10 (see esp. Ps 9 stanza V and Ps 10 stanza III). On the one hand the text carries the voice and function of the social reality in which it is situated, and on the other hand it is also a countervoice against the conventional and ideologically manipulated reality. ${ }^{5}$ The text thus breaks through the current social experience and seeks to create a new reality. The reality is also a function and a result of the text. It is therefore not only the circumstance or context that determines the text, but the text, in this case, is a prayer that may actually serve to transform and determine the situation.

The two Psalms are a political act, a voice of hope grounded in the knowledge that $\mathrm{YHWH}$ is the third party in all social relationships. By the confrontational rhetoric of the righteous the dominant ideology of the enemy is negated, as Brueggemann (1991:4) puts it aptly: '[T]o commit an act of social nullification of the enemy' and replace it with liberating imperatives that bring $\mathrm{YHWH}$ into action.

In Psalms 9 and 10 the enemy performs an essential and necessary function through which the righteous repositions himself in a harsh reality.

\section{Acknowledgements Competing interests}

The author declares that he has no financial or personal relationships which may have inappropriately influenced him in writing this article.

\section{References}

Balla, E., 1912, Das Ich der Psalmen, Vandenhoek \& Ruprecht, Göttingen. (Forschungen zur Religion und Literatur des Alten und Neuen Testamentes, 16).

5.See in this regard Jeismann (1985), who argued at length that texts (especially historical texts) have three major functions, namely identitätsstiftende Funktion, Legitimierungsfunktion and Orientierungsfunktion. Having the transformative Legitimierungsunktion and Orientierungsfunktion. Having the transformative power and function of stories and poems in mind Engelbert (1988:vili-ix) writes: 'Occasionally this amputation of history, coupled with rigid censorship, was successful in colonizing the imagination .... against the powerful ideologies imposing themselves in the isthmus, the ancient strategies of the embattled storyteller parable and allegory, parody and satire, fable and fantastic tale - were in colonial times, as now, invaluable arms in the struggle to ransom the abducted past, to delineate and to denounce a repressive present. 
Birkeland, H., 1955, The Evildoers in the Book of Psalms, Kommisjon Hos Jacob Dybwad, Oslo.

Botha, P.J., 1986, 'Die teologiese funksie van die Torah-woordveld in die driehoeksverhouding Jahwe-Vrome-Vyand in Psalm 119', DD proefskrif, Department Antieke Tale, Universiteit van Pretoria.

Botha, P.J., 1992, 'The function of the polarity between the pious and the enemies in Psalm 119', Old Testament Essays 5(2), 252-263.

Bowen, M., 1989, Family therapy in clinical practice, Aronson, New York, NY.

Brueggemann, W., 1991, 'Psalms 9-10: A counter to conventional social reality', in D. Jobling, P.L. Day \& G.T. Sheppard (eds.), The Bible and the politics of exegesis. Essays in honour of Norman K. Gottwald on his sixty-fifth birthday, pp. 3-16, Essays in honour of Norm

Christensen, D.L., 1992, s.v. 'Nations', in D.N. Freedman (ed.), The Anchor Bible Dictionary, pp. 1037-1048, Doubleday, New York, NY.

Coetzee, J.H., 1997, 'Putting words into the enemy's mouth: The investigation of rhetorical persuasion strategy in Psalm 9-10', Ekklesiastikos Pharos 79(1), 1-15.

Croft, S.J.L., 1987, The identity of the individual in the Psalms, JSOT Press, Sheffield.

Delekat, L., 1967, Asylie und Schutzorakel am Zionheiligtum: Eine Untersuchung zu den privaten Feindpsalmen, Brill, Leiden.

De Saussure, F., 1916, Course in general linguistics, Peter Owen, London.

Duhm, B., 1922, Kurzer Handkommentar zum Alten Testament XIV, K. Marti (ed.), Mohr, Tübingen.

Engelbert, J.A., 1988, 'Four walls eight windows', in R. Santos (ed.), And we sold the rain, pp. viii-xxiii, Seven Stories Press, New York, NY.

Gottwald, N.K., 1985, The Hebrew Bible: A socio-literary introduction, Fortress, Philadelphia, PA.
Gunkel, H. \& Begrich, J., 1985, Einleitung in die Psalmen: Die Gattungen der religiösen Lyrik Israels, Vandenhoeck \& Ruprecht, Göttingen.

Jeismann, K.-E., 1985, Geschichte als Horizont der Gegenwart, Schoningh, Paderborn.

Jenni, E., 1976, s.v. 'Feind', in E. Jenni \& C. Westermann (eds.), Theologisches Handwörterbuch zum Alten Testament, Bd. 1, pp. 118-122, Kaiser, München.

Kittel, R., 1922, Die Psalmen, E. Sellin, Leipzig. (Kommentar zum Alten Testament).

Lewis, I.M., 1976, Social anthropology in perspective: The relevance of social anthropology, Penguin, New York, NY.

Mowinckel, S., [1923] 1966, Psalmenstudien, Schippers, Amsterdam.

Puukko, A.F., 1950, 'Der Feind in den alten Psalmen', Oudtestamentische Studiën 8 , 47-65.

Rosenbaum, S.N., 1974, 'The concept "Antagonist" in Hebrew psalmography: A semantic field study', PhD thesis, Dept. of Near Eastern and Judaic Studies, University of Brandeis, Brandeis.

Sanders, J.A., 1976, s.v. 'Enemy', in G.A. Buttrick, K. George \& C. Buttrick (eds.), The interpreter's dictionary of the Bible, p. 101, Abingdon, Nashville, TN

Sawyer, J.F.A., 1972, Semantics in biblical research: New methods of defining Hebrew words for salvation, Student Christian Movement Press, London.

Sheppard, G.T., 1991, "Enemies" and the politics of prayer in the Book of Psalms', in D. Jobling, P.L. Day \& G.T. Sheppard (eds.), The Bible and the politics of exegesis: Essays in honour of Norman K. Gottwald on his sixty-fifth birthday, pp. 61-82, Pilgrim Press, Cleveland, OH.

Westermann, C., 1964, Forschung am Alten Testament, Kaiser, München.

Widengren, G., 1936, The Accadian and Hebrew Psalms of lamentation as religious documents: A comparative study, Thule, Uppsala. 